\title{
Entrepreneurial Social Competence and Entrepreneurial Orientation to Build SME's Business Network and Business Performance
}

Meutia

\begin{abstract}
A competence that is owned by entrepreneurs becomes a significant determinant to reach the business sucess becuase of the entrepereur's double role, as the owner and the manager itself. The purpose of this study is to overview the influence of entrepreneurial social comptence and entrepreneurial orientation on the developmnet of SME's business network and business performance in Western Java Province, of Indonesia. Sampling method uses Purosive Sampling Technique based on these criteria: at least 3 years experience and have had full tim employee. Sample which is used in this study, is the owner and the manager of SME, with total amount of respondents are 193. Data will be analyesed through Structural Equation Modeling (SEM) by using AMOS program 16.0. The result from this study shows that the first hypotheses proves that there is a significant influence of entrepreneurial social competence on business network. Meanwhile, entrepreneurial orientation gives no influence on business network, but it influences the SME's competitive advantage. Last hypothesis also shows that there is a signifcant relationship between SME's business network and SME's business performance. The result form this study provides contribution to Resource Based View (RBV) theory which states that there are intangible assets of entrepreneurial social competence in building the SME's business network and SME's business performance. Unfortunately, the present study does not analyse all creative industrial sector and the study is only performed in Western Java Province which becomes one of the main creative industries besides Yogyakarta and Bali in Indonesia.
\end{abstract}

Index Terms-Entrepreneurial social competence, entrepreneurial orientation, business network, business performance.

\section{INTRODUCTION}

Entrepreneurial term is often related with a new business creation and small business management [1]. An entrepreneur is a person that combines resources, workers, materials, and another asset to yield a bigger value than before [2]. A profile of a successful entrepreneur is an individual that has some characteristics, such as, assertive, strong self confidence, easily build a social relationship, single oriented, diplomatic, dare to take a risk and able to provide an appropriate judgment [3].

Annually, high development of creative industries in Indonesia will provide an opportunity to increase Indonesia's economy growth. Data from Statistic Bureau (Badan Pusat Statistic or BPS) stated that creative industries give contribution on bruto domestic development and placed it in

Manuscript received April 10, 2013; revised June 10, 2013.

Meutia is with Sultan Ageng Tirtayasa University, Banten-Indonesia (e-mail: tia_almer@yahoo.co.id.). the 7th rank of 10 sectors with export development in $2006-$ 2009 as $2.9 \%$. The study explains that the main problem faced by Indonesia is continuous invasion of foreign products that also occurred in creative industry. As a matter of fact, Indonesia has great sources to develop a culture based creative industry, because Indonesia has plentiful of natural and cultural resources. Regrettably, it is not in line with the nation's ability to build business network.

One aspect that can be considered to be material research is the analyses of whether the creative industry is influenced by the ability of an entrepreneur to build business network in improving business performance. Business network can be built based on entrepreneurial social competence which is owned by the entrepreneurs [4]. The result from this study also finds out that there is a positive relationship between entrepreneurial social competence and business network in batik industry in Indonesia [4]. Entrepreneurial social competence which is owned by entrepreneurs enables them to have social interaction and it will finally ease them to have a good communication both with external and internal party. Social competence enables an entrepreneur to get an easiness to access government support and they will be able to be more flexible in adapting with the environment dynamic change. Entrepreneurial social competence will be an alternative option for a company to reach its business network.

Most studies state that business performance will be influenced by entrepreneurial orientation which will be measured through some dimensions, such as, innovation, pro activeness, and risk taking [5]-[8]. Yet, some studies stated that the influence of entrepreneurial orientation on business performance will be lasted in short duration [9]. In addition, another studies also explained that there is no influence of entrepreneurial orientation on business performance as it has shown from [10]. This study explicitly investigates the relationship among entrepreneurial social competence, entrepreneurial orientation, business network, and business performance.

\section{Literature ReVIEW AND Hypotheses DeVElopment}

\section{A. Relationship between Entrepreneurial Social Competence and SME's Business Network and SME's Business Performance}

Entrepreneurial social competence is the ability of an entrepreneur to express their ability in building social relationship through the development of relational competence and social interaction which are based on family spirit, so as to build a business network with the business 
environment [4]. Entrepreneurial social competence constructs are build by the ability of an entrepreneur to build a social relationship, the ability to build on social relatedness with customer, the ability to build social relatedness with supplier, the ability to build social relatedness with business performers, the ability to build social relatedness with financial institution, the ability to build social relatedness with government environment, and the ability to build social relatedness with another professional organization.

Competence is as a core characteristic which is owned by a person who can change motivation and aspects from the skillfulness of personal image or social role which becomes a part of social capital [11]. Previous studies stated that the higher social capital (in a form of desired reputation, a larger social network, etc) will help an enterprise by giving them an important access to reach its success [12]. Nevertheless, if an access is tightly kept, social competence which is owned by an entrepreneur will influence the performance.

Entrepreneur's ability to make use resources capital to build a social relationship will be SME's competitive advantage. It may occur, since SME is started by a family business management which has strong business relationship by using a network which is based on family value. Empirical study has not clearly differentiated among information, social and business interaction. Many interactions especially in social relationship will influence the business performance. The ability to build social relationship will yield some benefit such as the larger business information, the strengthening business network and the adaptability with business environment, so as to compose unique resources in a company to reach its successful business performance [4]. Furthermore, it can be said that a person who has high social competence will be able to express more social attention, will be more sympathetic, more helpful and more loveable. These traits will ease them to have a smooth interaction, create a social relationship, and also create closed communication flow that will influence the business performance. Based on these arguments above and the result from previous studies, it can be formally stated:

- H1: The higher the entrepreneurial social competence the larger business network will be.

- H2: The higher the entrepreneurial social competence the higher business performance will be.

\section{B. Relationship between Entrepreneurial Orientation and} SME's Business Network and SME's Business Performance

Entrepreneurial is a motivation, a character, a willingness to work hard, not easily give up, and dare to take any risk. It is the ability to pursue any opportunity that becomes an important chance to have a high performance of business, by using the existing resources in reaching its success [13]. Entrepreneurial orientation is a company's orientation to have a main principle in its effort to identify and exploit any opportunities [8]. Lumpkin and Dess [8] add other characters, that is to say, aggressive competition and organization's independence besides risk taking, pro-activeness. A firm that has proper entrepreneurial orientation will have an ability to perform a better innovation compared with another company
[14]. Entrepreneurial orientation is an effort to be the best, both in product and market innovation, dare to take any risks, and pursue any chance to beat the competitor. Entrepreneurial orientation is a tendency of a company to be autonomous, more innovative, dare to take any risk, pursue any opportunity and being aggressive in a competition [15]. Literary review explains that current entrepreneurial orientation develops in a more various construct. The result from this study also explains the influence of entrepreneurial orientation on business performance as described by [16], [17].

Entrepreneurial orientation will push entrepreneurs to build a main business network through social capital so as to improve the business performance. Business network is identified as an opportunity to distribute a product and market inflation to anticipate any competition. Based on the arguments above, it can be formally stated that:

- H3: The higher the entrepreneurial orientation, the larger business network will be.

- H4: The higher the entrepreneurial orientation, the higher business performance will be.

\section{Relationship between SME's Business Network and SME's Business Performance}

Network theory explains that business network will ease the owner of a business to get an access to a unique resource through cost saving, it will also influence the business success [18]. Network will provide value to their member by letting them to get an access to social capital which is implanted in its network, in which the network itself, will provide a tool to the SME's owner to get external resources which is needed by their firm [19], [20].

Individual who has business network that consist of relatives and friends tend to have a bigger access to get an innovation, compared with business which does not have a network [21]. Fischer and Reuben [22] stated that the owner of a firm develop a relationship with external environment to improve business development. As a matter of fact, a company which has higher entrepreneurial orientation will tend to empower most part of their existing resources to create an optimum and better company's performance [23]. Based on the arguments above, it can be formally stated that:

- H5: The higher the development if business network, the higher SME's business performance will be.

\section{METHOD}

This study uses structural equation modeling as a multivariate analyses tool that enables the author to test the relationship between complex variables and they can also obtain a full description on the entire model. SEM has been considered as a statistic tool that is useful for the researchers in social science. SEM had been a must for non experimental study, in which the testing method to test the theory has not been fully developed. This study uses software AMOS 16 as the aid tool to solve SEM's problem. Sampling method used in this study is based on a certain criteria. Respondents that 
are selected based on certain criteria such as, at least 3 years experience, and already have full employee and national marketing scope. Data for this study will be opted by distributing questionnaires to the owner and the manager of creative industries in Western Java, Province of Indonesia. Each questionnaire uses 7 point of likert scale. Point 1 shows an indication of "absolutely disagree" and point 7 shows an indication of "absolutely agree". There are 193 respondents that met the criteria will be tested in this study. Structural Equation Modeling (SEM) with AMOS 16.0 program as the aid tool requires 100 respondents as minimum amount [24].

Indicators which are used to measure the entrepreneurial social competence will be adapted from the research result [4]. These indicators are (a) the ability to build social relationship, (b) the ability to build business relationship based on social relatedness, (c) the ability to build social relatedness with employee, (d) the ability to build social relatedness with customer, (e) the ability to build social relatedness with suppliers, (f) the ability to build social relatedness with business performers, $(\mathrm{g})$ the ability to build social relatedness with financial institution, (h) the ability to build social relatedness with government environment, and (i) the ability to build social relatedness with professional organization.

Entrepreneurial orientation is the tendency of an entrepreneur to have innovation, dare to take a risk, and proactiveness. Indicators to measure the entrepreneurial social competence are (a) Innovation, (b) Risk Taking, (c) Proactiveness and (d) being aggressive in competition [8], [25]. Indicators to measure business network are (a) the amount of business network with production sector, (b) the amount of network with suppliers, (c) the amount of business network with distribution channel [33]. SME's business performance is the attained result from what manager and owner has done to manage their business. Indicators to measure the business performance assessment are (a) sales development, (b) working capital development, (c) customer development and (d) profit growth [9], [25], [26], [27].

\section{RESUlt AND Discussion}

\section{A. Sample Size}

Samples which are used in this study are 193 respondents. This amount of sample has met the requirement of data analyses, by using Structural Equation Modeling (SEM). Hair et al [24] stated that the appropriate amount of sample is in the range of 100 till 200 respondents by using Maximum Likelihood Estimation.

\section{B. Outliers Testing}

Outliers is the observed condition of data which has unique characteristic and has different characteristic from another observation and it comes out as an extreme shape both in single and combination variables [24]. Multivariate outliers evaluation will be performed by using mahalanobis distance calculation for each variable. Mahalonobis distance shows that there is a distance of a certain variable from the average variables in multidimensional space. Mahalonobis distance calculation is based on chi square value in $\chi^{2}$ distribution table at the degree of freedom as the used indicators in this study. This study uses 16 indicators at $p<0.001$ as $\chi^{2}$ $(160.001)=39.25$. Therefore, data in this study has mahalanobis distance which is bigger than 39,25 and it is considered as multivariate outliers. Based on the result of mahalanobis distance calculation, the largest value is 37.928 , which means that it is below the required value as 39,25 , as a result there is no outliers.

\section{Multicolinearity Testing}

Multicolinearity testing can be seen from determinant of matrix covariance. If the value of determinant matrix covariance is too small, there is an indication of multicolinearity, as a result data cannot be used. AMOS output result shows the determinant matrix covariance as 0,058 . The value of determinant matrix covariance is larger than 0 , so it can be concluded that there is no multicolinearity in this study [28].

\section{Normality Testing}

The value of normality testing by using critical value is 2.58 at significant rate as 0.01 . If $\mathrm{Z}$ value is more than the critical value, it can be assumed that the data distribution in this study is not normal [29]. Normality testing shows that $\mathrm{cr}$ value is 1,858 which means that this value is in the range of required value at $\pm 2,58$ at significant rate as 0,01 .

\section{E. Adequacy Testing}

The result of data analyses by using AMOS program states that the result testing of SME's business performance is considered adequate since the value is in good of fit index range. Based on the adequacy testing it can be seen as the Fig. 1 .

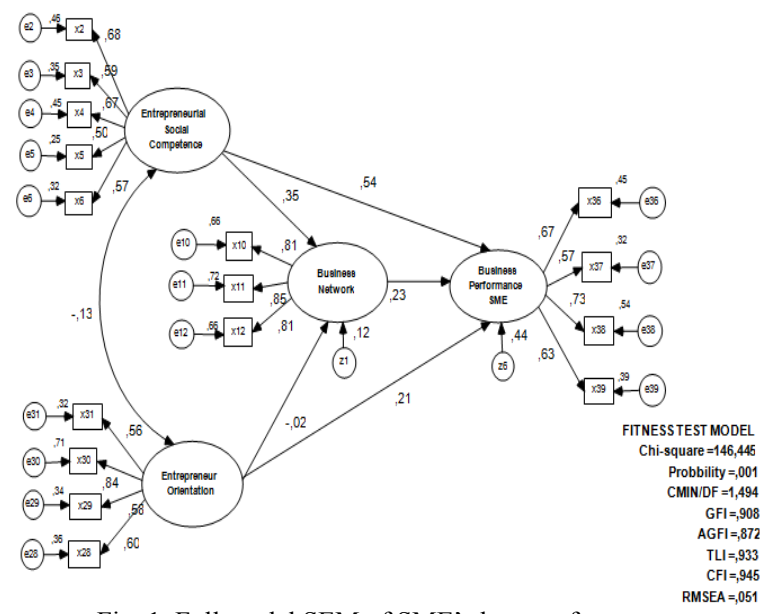

Fig. 1. Full model SEM of SME's bus. performance

The result of hypotheses testing at Table I shows that entrepreneurial social competence influence the business network. Entrepreneurial orientation gives no influence on business network. Entrepreneurial social competence influences the SME's business performance, and the business network influences the business performance. The result of hypotheses testing result by using AMOS program 16.0 can be read at Table I.

Estimation parametric to test the influence of entrepreneurial social competence on business network shows a significant result with cr value as 4,474 at significant rate as 0.001 . The value meets the hypotheses acceptance 
requirement as cr value $>1.96$ which means that there is no reason to deny hypotheses 1 . Based on the above result, it can be concluded that entrepreneurial social competence influences the business network. Entrepreneurial social competence in this study is formed through the ability of an entrepreneur to build business relation based on their social, relatedness with their employee, customers, suppliers, other business performers and also with financial institution.

TABLE I: REGRESSION WEIGHTS

\begin{tabular}{lllcccc}
\hline & & & Estimate & S.E. & C.R. & P \\
\hline Bus. & $<-$ & Entre. Social & &, 12 & & \\
Net & - & Competence &, 442 & 5 & 3,54 & $* * *$ \\
Bus. & $<-$ & Entre. & &, 10 & & \\
Net & - & Orientation &,- 022 & 2 &,- 21 &, 831 \\
Bus. & $<-$ & Entre. Social & &, 13 & & \\
Perf & - & Competence &, 612 & 7 & 4,47 & $* * *$ \\
Bus.Per & $<-$ & Bus. & &, 07 & & \\
f & - & Network &, 209 & 9 & 2,63 &, 008 \\
Bus.Per & $<-$ & & &, 09 & & \\
$\mathrm{f}$ & - & Entre. Orien. &, 223 & 8 & 2,26 &, 024 \\
\hline
\end{tabular}

The result from this study is in line with the previous study which stated that there is an influence of entrepreneurial social competence of business network in batik industry [4]. The value that comes out from social interaction will strengthen the entrepreneur relationship among partner in building business relationship to enhance marketing development of SME's product. Facing the change of SME globalization will also increase the competitiveness of an entrepreneur through their business network development.

Estimation parametric to test the influence of entrepreneurial social competence on business performance shows a significant result with cr value as 3.539 at significant rate as 0.001 . The value meets the hypotheses acceptance requirement as cr value $>1.96$ which means that there is no reason to deny hypotheses 2 .

Based on the empirical result, it shows that the ability to build business relationship which is based in social relatedness will be one of the stimulating factors to increase sales volume. Business relationship which is made based on social relatedness will survive in a longer period of time [4]. Wright et al [30] stated that human resources capability is a collective knowledge from each member of a company (hard to imitate) that is developed in a certain period of time (rare), and it is considered as valuable sources since it will drive the company to its success. Entrepreneurial social competence is one of human resources capability which is hard to imitate. Previous studies indicated that the importance of core competence and external business network to reach the optimal performance are based on social based view and resources based view [31].

Estimation parametric to test the influence of entrepreneurial social competence on business network shows a negative cr value as $-0,213$ with probability as 0.831 . The value does not meet the hypotheses acceptance requirement as cr value $<1.96$ which means that there is no reason to accept hypotheses 3 . In other words, innovation risk taking, pro activeness, being aggressive in competition, in this study give no influence on business network development.

Estimation parametric to test the influence of entrepreneurial orientation on business performance shows a significant result with cr value as 4,474 at significant rate as 0.024 . The value meets the hypotheses acceptance requirement as cr value $>1.96$ which means that there is no reason to deny hypotheses 1 .

These result support the results from previous studies [16], [17], which stated that there is a positive relationship between entrepreneurial orientation with business performance. The characteristics of entrepreneurial such as innovation, risk acceptance, will also help the entrepreneurs to anticipate the new market, and improve the innovative ideas, as well as give proactive influence on business performance. Dare to take a risk reflects the tendency to empower entire resources in an integrated activity which may either fail or succeed and get an enormous profit [8]. Next, a trait to take an opportunity is the ability of entrepreneurs to take an aggressive initiative in performing their business and becomes the leader in shaping business environment which will get big profit. Support for any new ideas is the tendency of an entrepreneur to get new ideas, creative process that deviate from the existing practice. An entrepreneur who has high level of creativity and uniqueness will give more significant influence on SME's business performance.

Estimation parametric to test the business network on business performance shows a significant result with cr value as 2.4632 with probability 0.008 . The value meets the hypotheses acceptance requirement as cr value $>1.96$ which means that there is no reason to deny hypotheses 1 . Based on the result above, it can be concluded that the larger the business network, the higher the business performance will be. Network theory stated that the ability of an entrepreneur to get a rare access through saving cost network will influence the business' success [18]. Network can improve the social capital of SME's owner [32] since it will give an access to any information which is planted in the existed network. Granovetter [21] stated that an individual who has business relationship that consists of relatives and friends tends to have an access to a larger amount of information compared with another business that does not have a network. Previous studies indicated the importance of core competence and external business network to reach the optimum performance described social model are based on resources [31].

\section{CONCLUSION, IMPLICATION AND LIMITATION}

The present study tries to overview the influence of entrepreneurial social competence on creative industries in developing SME's business performance and business in Indonesia, especially in Western Java Province. Entrepreneurial orientation will be an additional variable in building the model to see its contribution on business network and business performance development. The study builds a hypothesis that all construct will give an influence business performance. The result from this study shows that five hypotheses built in entrepreneurial social competence will influence the business network and business performance development, entrepreneurial orientation will influence the business performance and business network will influence the business performance. The result from this 
study is in line with the result from previous studies. Yet, entrepreneurial orientation gives no influence in building business network.

Theoretically, the result from this study will explain that there is a different opinion from previous studies in enhancing a new reference, especially with the addition of new variable that is entrepreneurial social competence as a core competence that can be developed in entrepreneurial domain to improve the business success in every business unit.

Limitation in this study is that the study is performed only in one province, which is Western Java Province besides Yogyakarta, and Bali. The present study does not observe all components in creative industry but only focusing in handicraft industry. Future study can be tested in another domain of creative industry that also becomes the centre of creative industry.

\section{ACKNOWLEDGMENT}

I would like to acknowledge and extend my heartfelt gratitude to Prof. Dr. H. Miyasto, SU, Prof. Dr. Augusty Tae Ferdinand, MBA, Dr. Ibnu Widiyanto, MA \& my colleagues at Sultan Ageng Tirtayasa University whose help, stimulating suggestions, knowledge, experience and encouragement helped me in finishing this paper. I would also like to thank to my husband, Tubagus Ismail, and our children Tubagus Pasca Faiz Ikram, Ratu Shafa Raudha Alisha and Tubagus Airlanga Zia Almer for their support and encouragement.

\section{REFERENCES}

[1] A. A. Gibb, "Entrepreneurship and small business management: can we afford to neglect them in the twenty-first century business school?' British Journal of Management, vol. 17, no. 4, pp. 309-324, 1996.

[2] Hirsch, Entrepreneurship, 8th Edition, McGraw-Hill/Irwin, 20 Nov. 2009.

[3] B. Cunningham and J. Lischeron, "Defining entrepreneurship," Journal of Small Business Management, vol. 29, no. 1, pp. 45-61, 1991.

[4] Meutia, "Pengembangan kompetensi sosial kewirusaan untuk meningkatkan keunggulan bersaing dan kinerja bisnis ukm. ukm batik di kota pekalongan," PhD Theses, Undip., Semarang, 2012.

[5] N. C. Churchill and V. L. Lewis, "The five stages of small business growth," Harvard Business Review, vol. 61, no. 3, pp. 1-12, 1983.

[6] J. L. Namman and D. P. Slevin, "Entrepreneurship and the concept of fit: a model and empirical tests," Strategic Management Journal, vol. 14, no. 2, pp. 137-153, 1993.

[7] P. H. J. Sugiarto, "Peran orientasi kewiraswastaan dalam mengatasi konflik fungsional untuk menciptakan strategi yang berorientasi pada kinerja bisnis," Disertasi Program Doktor Ilmu Ekonomi Universitas Diponegoro, 2008.

[8] G. T. Lumpkin and G. G. Dess, "Clarifying the entrepreneurial orientation construct and linking it to performance," Academy of management Review, vol. 21, no. 1, pp. 135-172, 1996.

[9] J. Wiklund, "The sustainability of the entrepreneurial orientationperformance relationship," Entrepreneurship: Theory Dan Practice, vol. 24, no. 1, pp. 37-49, 1999.

[10] J. B, Huck and T. McEwen, "Competencies need for small business success: perceptions of Jamaican entrepreneurs," Journal of Small Business Management, Oktober, pp. 90-93, 1991.

[11] R. E. Boyatzis, The competent manager: a model for effective performance, John Wiley Adan Sons, New York, NY, 1982.

[12] M. Baron, "Beyond social capital: the role of entrepreneurs' social competence in their financial success," Journal of Business Venturing vol. 18, pp. 41-60, 2003.

[13] G. Meredith and M. Geoffrey, "Kewirausahaan: teori dan praktek," Jakarta: Pustaka Binaman Resindo, 1996.

[14] D. Miller, "The correlates of entrepreneurship in three types of firms," Journal of Management science, vol. 29, pp. 770-791, 1983.
[15] M. Miles and D. Arnold, The relationship between marketing orientation and entrepreneurship orientation, Bayler University, 1991.

[16] I. H. Chow, "The relationship between entrepreneurial orientation and firm performance in China," Advance Management Journal, Sumer, pp. 11-20, 2006.

[17] Lee, "The effect of entrepreneurial and knowledge management capability on organizational effectiveness in Taiwan: the moderating of social capital," International Journal of Management, vol. 24, no. 3, pp. $549,2007$.

[18] L. Zhao and J. D. Aram, "Networking and growth of young technology-intensive ventures in China," Journal of Business Venturing, vol. 10, no. 5, pp. 349-370, 1995.

[19] C. J. Jarillo, "On strategic networks," Strategic Manag. Journal, pp. $31-41,1988$.

[20] J. Lubatkin, M. Florin, and W. Schulze, "A social capital model of high-growth ventures," Academy of Management Journal, vol. 46, pp. 374-396, 2003.

[21] M. S. Granovetter, "Economic action and social stucture the problem in embededness," American Journal of Sociology, vol. 91, pp: 481-510, 1985.

[22] E. Fischer and R. A. Reuber, "Support for rapid-growth firms: a comparison of the views of founders, government policymakers, and private sector resource providers," Journal of Small Business Management, vol. 41, no. 4, pp. 346-365, 2003.

[23] C. N. Chen, "The relationship among social capital, entrepreneurial orientation, organizational resources and entrepreneurial performance for new ventures," Contemporary Management Research, vol. 3, no. 3, pp. 213-232, September 2007.

[24] J. F. Hair, W. C. Black, B. J. Babin, and R. E. Anderson, "Multivariate Data Analysis," Seventh Edition, London: Prentice-Hall International (UK) Limited, 2010.

[25] W. Stamp and T. Elfring, "Entrepreneurial orientation and new venture performance: the moderating role of intra- and Extra industry social capital," Academy of management journal, vol. 51, no. 1, pp. 97-111, 2008.

[26] J. Wiklund and D. A. Shepherd, "Entrepreneuril orientation and smll business performance: a Configurational Approach," Journal of Business Venturing, vol. 20, Issue 1, pp. 71-91, 2005.

[27] S. I. Krauss and F. Michale, "Entrepreneurial orientation: a physiological model of success among southern African small business owners," Europian journal of work and organizational psychology, vol. 14, no. 3, pp. 315-344, 2005.

[28] I. Ghozali, "SEM konsep dan aplikasi dengan program amos 21," BP Universitas Diponegoro, 2004.

[29] A. T. Ferdinand, "Metode penelitian manajemen," Edisi 2. Penerbit Universitas Diponogoro, Semarang, 2006.

[30] P. Wright, G. McMahan, B. McCormick, and S. Sherman, "Strategy, core competence, and human resource involvement as determinants of HR effectiveness and refinery performance," Human Resource Management, vol. 36, pp. 17-29, 1998.

[31] C. Lee, K. Lee, and J. M. Pennings, "Internal capabilities, external networks, and performance: a study on technology-based ventures," Strategic Management Journal, vol. 22, pp. 615-640, 2001.

[32] J. S. Coleman, "Social capital in the creation of human capital," American Journal of Sociology, vol. 94, pp. 95-120, 1988.

[33] I. Björkman and S. Kock, "Social relationships and business networks: the case of western companies in China," International Business Review, vol. 4, no. 4, pp. 519-535, 1995.

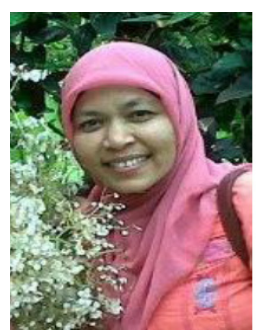

Meutia was born in Mns. Teungoh, Aceh-Indoneisa on 28 August 1972. She obtained her Master in 1999 from Padjajaran University, Bandung - Indonesia. She obtained her Doctorate in Management in 2012 from Diponegoro University, Semarang-Indonesia. She is a lecturer in Agribusiness Department, Agriculture Faculty, Sultan Ageng Tirtayasa University, Banten-Indonesia. Her current research interest in Entrepreneurship. Some of her Published works are: Strategy, Management Control System and National Culture: A Case Study of Batik Industry in Indonesia (Journal of Procedia Social and Behavioral Sciences Vol. 65, pp. 33-38, December 2012, Published by Elsevier); The Development of Entrepreneurial Social Competence and Business Network to Improve Competitive Advantage and Business Performance of Small Medium Sized Enterprises: A Case Study of Batik Industry In Indonesia (Journal of Procedia Social and Behavioral Sciences vol. 65, pp 46-51, December 2012, Published by Elsevier). 